\title{
PENGEMBANGAN MEDIA PEMBELAJARAN POP UP BOOK BERBASIS BUDAYA BANTEN PADA MATA PELAJARAN MATEMATIKA DI KELAS IV SEKOLAH DASAR
}

\author{
Kamilah Ramadhanti ${ }^{1}$, Indhira Asih V.Y. ${ }^{2}$, Trian Pamungkas Alamsyah ${ }^{3}$ \\ Mahasiswa Pendidikan Guru Sekolah Dasar, FKIP, Universitas Sultan Ageng Tirtayasa ${ }^{1}$ \\ Dosen Pendidikan Guru Sekolah Dasar, FKIP, Universitas Sultan Ageng Tirtayas ${ }^{2,3}$ \\ e-mail: Kamilahr98@gmail.com
}

\begin{abstract}
ABSTRAK
Penelitian ini bertujuan untuk mengembangkan media pembelajaran berupa pop up book berbasis budaya Banten pada mata pelajaran matematika di kelas IV Sekolah Dasar dan untuk mengetahui respon siswa setelah melaksanakan proses pembelajaran dengan menggunakan media pembelajaran pop up book berbasis budaya Banten. Penelitian ini menggunakan metode penelitian dan pengembangan meliputi 3 tahap yaitu, tahap pendefinisian (define), tahap perencanaan (design) dan tahap pengembangan (develop). Media pop up book ini dilakukan uji validasi ahli, diantaranya ahli materi dan ahli media. Setelah dilakukan uji coba oleh tim ahli, selanjutnya dilakukan uji coba produk dengan subjek penelitian yaitu 19 siswa kelas IV B SDN Kebaharan 1. Hasil uji ahli media pop up book ini memperoleh rata-rata skor validasi ahli sebesar 89\% sehingga mendapat kategori "sangat layak" dan hasil uji coba produk (uji coba terbatas) mendapat rata-rata skor sebesar 84,7\% dengan kategori "sangat baik". Jadi, dapat disimpulkan media pop up book berbasis budaya Banten ini layak dan dapat dipergunakan.
\end{abstract}

Kata Kunci: Media Pop Up Book, Budaya Banten, Matematika, Sekolah Dasar

\begin{abstract}
This study aims to develop learning media in the form of pop up books based on Banten culture on mathematics in grade IV elementary schools and to determine student responses after implementing the learning process using learning media pop up book based on Banten culture. This study uses a research and development method including 3 stages, namely, the define stage, the planning stage (design) and the development stage. This media pop up book was subjected to expert validation tests, including material experts and media experts. After testing by a team of experts, a product trial was carried out with the research subjects, namely 19 grade IV B students of SDN Kebaharan 1. The results of this media expert test pop up book obtained an average expert validation score of $89 \%$ so that it got the "very feasible" category and the results of product trials (limited trials) got an average score of $84,7 \%$ in the

" very good "category. So, it can be concluded that the media pop up book based on Banten culture is feasible and can be used.
\end{abstract}

Keywords: Media Pop Up Book, Banten Culture, Mathematics, Elementary School

\section{PENDAHULUAN}

Pendidikan adalah salah satu kebutuhan yang sangat penting bagi kehidupan manusia karena dengan pendidikan dapat membantu seseorang memiliki kecerdasan, mampu menggali dan mengembangkan potensi yang ada dalam dirinya serta membentuk kepribadian yang baik untuk menjadi seseorang yang bermartabat.

Pendidikan di sekolah dasar sangat penting karena menjadi pondasi bagi jenjang sekolah yang lebih tinggi karena pendidikan pada jenjang yang lebih tingggi merupakan kelanjutan dan kesinambungan dari pendidikan dasar. Melalui pendidikan dasar hendaknya peserta didik akan dibekali 
dengan kemampuan dasar yang terkait dengan kemampuan berpikir kritis, kemampuan membaca, menulis, berhitung. Kemampuan tersebut penting untuk dikuasai peserta didik sebagai dasar-dasar untuk mempelajari saintek dan kemampuan berkomunikasi sebagai tuntutan kemampuan minimal yang harus dimiliki dalam kehidupan bermasyarakat (Muhammad Ali, 2009).

Pembelajaran matematika di Sekolah Dasar memegang peranan penting karena pendidikan dasar menjadi pondasi untuk pendidikan selanjutnya. Pembelajaran matematika adalah suatu proses belajar mengajar yang dibangun oleh guru untuk mengembangkan kreatifitas berpikir siswa yang dapat meningkatkan kemampuan berpikir siswa, serta dapat meningkatkan kemampuan mengkontruksi pengetahuan baru supaya meningkatkan penguasa yang baik terhadap materi matematika (Susanto, 2013).

Namun, masalah yang umumnya dihadapi siswa dalam belajar adalah mengenai kurangnya minat sebagian siswa pada mata pelajaran tertentu, seperti penelitian yang telah dilakukan sebelumnya yang menyatakan bahwa para siswa cenderung kurang menyukai pelajaran matematika, hal tersebut dikarenakan materi yang terdapat pada pembelajaran matematika dianggap sukar bagi siswa, selain itu terdapat banyak rumus-rumus dalam materi matematika (Alfi Nur Santi, 2016). Kurangnya minat pada mata pelajaran matematika menjadi kendala bagi siswa dalam memahami pelajaran matematika seperti permasalahan yang terjadi pada sebagian siswa kelas IV saat ini masih belum menguasai pembagian dan perkalian.

Pada proses pelajaran matematika di sekolah guru masih terpaku pada metode ceramah. Seperti yang diungkapkan oleh Turmudi mengemukakan bahwa pembelajaran matematika selama ini disampaikan kepada siswa secara informatif, artinya siswa hanya memperoleh informasi dari guru saja sehingga derajat kemelekatannya juga dapat dikatakan rendah (Rahmi Fuadi, 2016). Proses pembelajaran hendaknya terjadi dengan melakukan komunikasi dua arah antara guru dan siswa agar pembelajaran berjalan dengan efektif dan dapat mencapai tujun pembelajaran.

Melihat hal tersebut maka dalam pembelajaran di kelas diperlukan media pembelajaran sebagai pengantar komunikasi antara guru dan siswa. Media pembelajaran adalah segala sesuatu yang dapat digunakan untuk menyalurkan informasi dari pengirim ke penerima sehingga dapat merangsang pikiran, perasaan, perhatian dan minat serta kemauan peserta didik dalam belajar sehingga dapat mencapai tujuan pembelajaran secara efektif (Sukiman, 2012).

Melalui media pembelajaran dapat membantu guru dalam menyampaikan materi pembelajaran kepada siswa, selain itu dapat mempermudah siswa dalam memahami materi serta dapat menumbuhkan semangat belajar siswa karena pembelajaran yang dilakukan tidak monoton. Media pembelajaran merupakan salah satu penyalur pesan atau informasi dalam belajar, sehingga dalam merancang media pembelajaran guru perlu memperhatikan beberapa hal seperti, kualitas media, manfaat dan kesesuaian dengan konteks pembelajaran.

Maka, berdasarkan permasalahan yang ada di sekolah dasar dan permasalahan yang ada pada penelitian sebelumnya mendorong peneliti untuk memberikan inovasi dalam pembelajaran yaitu pengembangan media pembelajaran berupa pop up book berbasis budaya Banten.

\section{METODE PENELITIAN}

Penelitian ini menggunakan metode penelitian dan pengembangan atau Research and Development (R\&D) yaitu metode penelitian yang digunakan untuk menghasilkan produk tertentu, dan menguji keefektifan produk yang telah di rancang 
supaya dapat berfungsi di masyarakat luas (Sugiyono, 2015).

Desain penelitian ini mengacu pada desain pengembangan $3-D$, desain ini disarankan oleh Thiagarajan, semmel dan semmel dalam (Trianto, 2012). Prosedur penelitian yang diterapkan dalam penelitian ini adalah prosedur penelitian pengembangan produk media pembelajaran pop up book. Prosedur penelitian pengembangan menurut Thiagrajan, dkk hanya meliputi 3 tahap yaitu, tahap pendefinisian (define), tahap perencanaan (design), dan tahap pengembangan (develop).

Instrumen yang digunakan untuk mengumpulkan data pada penelitian ini adalah angket penilaian uji ahli, angket ini digunakan untuk menguji kualitas media dan materi pembelajaran dalam media pop up book. Untuk uji ahli terdiri dari 2 bidang, yaitu ahli materi dan ahli media pembelajaran. Selanjutnya, media yang telah melalui penilaian uji ahli akan di uji cobakan kepada siswa.

\section{HASIL DAN PEMBAHASAN}

Hasil penelitian pada pengembangan media pembelajaran ini dilakukan berdasarkan prosedur pengembangan pada model 3D yaitu melakukan pendefinisian (define), perencanaan (design) dan pengembangan (develop). Tahap-tahapnya ialah sebagai berikut:

\section{Pendefinisian (define)}

Pada tahap Define ini akan dilakukan analisis yakni analisis yang dilakukan berupa analisis kurikulum, analisis kebutuhan, dan analisis materi. Analisis yang dilakukan ialah sebagai berikut:

1) Analisis Kurikulum

Kegiatan menganalisis kurikulum adalah kegiatan yang peneliti lakukan untuk menelaah kurikulum yang digunakan di Sekolah Dasar pada mata pelajaran Matematika.
Analisis kurikulum dilakukan dengan cara menganalisis KD lalu merumuskan ke dalam indikator pembelajaran, dari indikator tersebut selanjutnya diturunkan menjadi tujuan pembelajaran. Kompetensi dasar pada materi bangun datar terdapat pada KD 3.9 Menjelaskan dan menentukan keliling dan luas persegi, persegi panjang dan segitiga serta hubungan pangkat dua dengan akar pangkat dua. Indikator pembelajaran 3.9.1 Mengenal dan memahami bangun datar (persegi, persegi panjang, dan segitiga). 3.9.2 Menentukan keliling dan luas persegi, persegi pajang dan segitiga. Tujuan pembelajaran (1) Dengan menggunakan media pembelajaran dan melakukan tanya jawab, siswa mampu mengenal dan menjelaskan bangun datar (persegi, persegi panjang, dan segitiga) dengan benar. (2) Dengan menggunakan media pembelajaran dan berdiskusi, siswa mampu menentukan keliling dan luas persegi, persegi panjang, dan segitiga dengan tepat.

2) Kegiatan menganalisis kebutuhan adalah kegiatan yang dilakukan oleh peneliti untuk mengetahui kebutuhan dalam proses pembelajaran di sekolah yang peneliti amati, analisis kebutuhan dilakukan dengan cara mengumpulkan informasi. Informasi tersebut di kumpulkan dengan cara melakukan observasi dan wawancara. Berdasarkan hasil wawancara guru mengatakan bahwa pembelajaran matematika khususnya materi bangun datar guru menggunakan media gambar dan media yang ada di sekitar.

3) Kegiatan analisis materi dilakukan untuk lebih memahami materi yang akan dimuat dalam pengembangan media pembelajaran pop up book yaitu bangun datar. Materi yang terdapat pada media pembelajaran telah melalui penyesuian materi yang dibutuhkan di kelas IV Sekolah Dasar. Materi yang akan dibahas meliputi bangun datar (persegi, persegi 


\section{$\pi$ (Phi)}

panjang dan segitiga) sesuai dengan kompetensi dasar yang termuat dalam kurikulum 2013. Analisis materi ini dilakukan agar terjadi kesesuaian antara materi yang termuat dalam media pembelajaran dengan kompetensi dasar yang terdapat pada materi bangun datar.

\section{Perencanaan (design)}

Setelah didapatkan bahan untuk membuat media pembelajaran pada tahap pendefinisian (define), kemudian dilanjutkan dengan tahap perencanaan (design), pada tahap ini dilakukan pengumpulan data dari berbagai informasi. Data yang dikumpulkan antara lain pengumpulan materi bangun datar, kemudian mengumpulkan gambar yakni gambar yang digunakan pada media pop up book merupakan gambar yang didapat dari internet. Gambar yang digunakan tentunya gambar yang sesuai dengan karakteristik siswa seperti gambar animasi, gambar bangunan yang ada di banten seperti bangunan masjid pacinan tinggi Banten, situs pengindelan abang dan rumah adat Sulah nyada serta peninggalan sejarah banten lainnya. Data yang digunakan tersebut menjadi referensi dalam mengembangkan media pembelajaran.

Tahap pertama dalam pembuatan media pop up book yakni membuat rancangan awal berupa storyboard. Pengembangan media pembelajaran yang dihasilkan terdiri dari tiga bagian yaitu bagian awal, inti dan akhir:

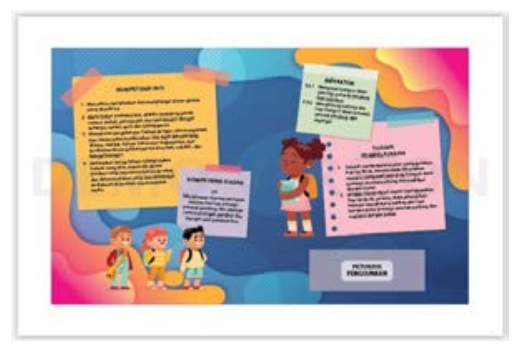

Gambar 1. Bagian Awal

Pada bagian awal media menampilkan kometensi inti, komptensi dasar, indikator, dan tujuan pembelajaran. serta dilengkapi dengan panduan cara menggunakan media pop up book.

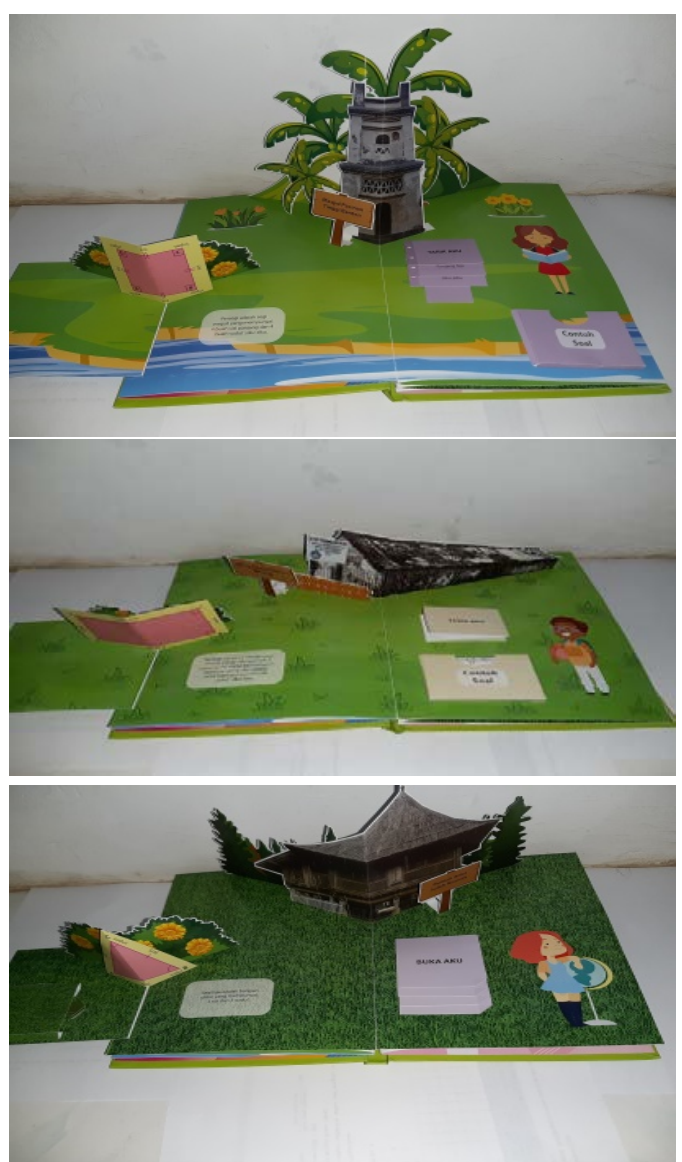

Gambar 2. Bagian Isi

Pada bagian selanjutnya menampilkan pengertian, sifat-sifat dan rumus bangun datar (persegi, persegi panjang dan segitiga), kemudian dilengkapi dengan contoh soal mengenai luas dan keliling dari gambar bangunan masjid pacinan tinggi Banten, situs pengindelan abang dan rumah ada sulahnyada khas suku Baduy. Teknik yang digunakan pada bagian isi tersebut ialah teknik Flaps, teknik Internal Stand dan teknik Pull-tabs. 


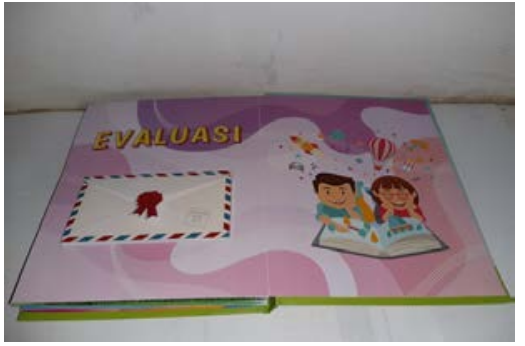

Gambar 3. Bagian Akhir

Pada bagian akhir menampilkan evaluasi berupa soal-soal yang berhubungan dengan bangun datar (persegi/ persegi panjang dan segitiga), soal-soal tersebut terdapat dalam kantong.

\section{Pengembangan (develop)}

Pada tahap ini dilakukan dengan tujuan untuk menyempurnakan media pembelajaran pop up book berbasis budaya Banten yang telah dibuat agar lebih baik setelah melalui revisi berdasarkan uji kelayakan dan saran-saran dari tim ahli dalam bidangnya.

Setelah media selesai melalui tahap pembuatan, maka tahap selanjutnya adalah validasi media. Validasi pada penilaian ini divalidasi oleh 2 ahli, yakni 2 ahli materi, 2 ahli media. Setelah data diolah dan melakukan revisi terhadap media pembelajaran. Penilaian bertujuan untuk memperoleh masukan revisi terhadap media pembelajaran. Penilaian bertujuan untuk memperoleh masukan, saran, pendapat serta evaluasi terhadap media pembelajaran yang disusun. selanjutnya dilakukan revisi berdasarkan masukan dari para ahli. Validasi juga bertujuan untuk mengetahui layak tidak layaknya media pembelajaran yang dikembangkan. Berikut adalah tabel penilaian ahli:

Tabel 1. Hasil Uji Validasi Ahli

\begin{tabular}{cccc}
\hline No & Ahli & Persentase & Keterangan \\
\hline 1 & Materi & $94 \%$ & Sangat Layak \\
2 & Media & $84 \%$ & Sangat Layak \\
\hline
\end{tabular}

Media pembelajaran pop up book berbasis budaya Banten yang telah divalidasi serta direvisi berdasarkan komentar dan saran dari tim ahli materi dan ahli media kemudian dilakukan uji coba terbatas. Uji coba ini dilakukan untuk mengetahui respon siswa terhadap media pembelajaran yang telah di buat dan telah selesai melalui uji ahli. Pada uji coba terbatas ini siswa diberi lembar angket dengan 3 aspek penilaian yang terdiri dari tiga aspek yaitu aspek kualitas media, aspek kualitas materi dan aspek kulitas teknis. Angket respon siswa digunakan untuk memperoleh data mengenai respon siswa terhadap media pembelajaran pop up book berbasis budaya Banten.

Uji coba terbatas ini dilakukan pada tanggal 27 Agustus 2020. Kelas IV B Sekolah Dasar Negeri Kebaharan I menjadi sampel dalam penelitian ini sekaligus menjadi tempat untuk menguji coba media pop up book. Jumah responden sebanyak 19 siswa. Hasil Uji coba terbatas mendapat jumlah presentase nilai akhir yaitu diperoleh mencapai 84.7\% dan berdasarkan pedoman konversi data kuantitatif ke kualitatif maka media pembelajaran pop up book masuk ke dalam kategori "sangat baik". Hasil penilaian uji coba terbatas pada media pembelajaran berupa pop up book pada setiap aspek dapat dilihat pada gambar berikut:

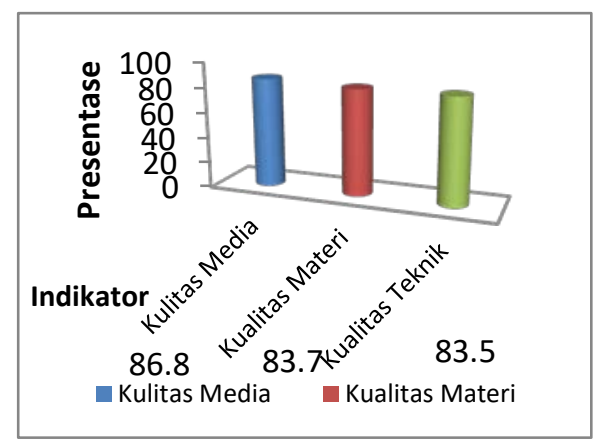

Gambar 4. Hasil Penelitian 


\section{Pembahasan}

Berdasarkan deskripsi hasil penelitian yang telah diuraikan sebelumnya, pengembangan media pembelajaran berupa pop up book berdasarkan model pengembangan 3D (Three-D) melalui 3 tahapan yakni, tahapan pendefinisian (define), perancangan (design), dan pengembangan (develop). Pada tahap pendefinisian dilakukan dengan beberapa analisis yaitu, analisis kurikulum, analisis kebutuhan, dan analisis materi (Trianto, 2012). Hasil dari analisis kurikulum yang dilakukan, SDN Kebaharan I menggunakan kurikulum 2013. Analisis kurikulum dilakukan dengan cara menganalisis KD lalu merumuskan ke dalam indikator pembelajaran, dari indikator tersebut selanjutnya diturunkan menjadi tujuan pembelajaran. Hal tersebut sesuai dengan pejelasan bahwa pembelajaran berisi rangkaian kegiatan yang direncanakan dan disusun dengan sedemikian rupa untuk mendukung dan memengaruhi terjadinya proses belajar siswa yang bersifat internal (Aunurrahman, 2010).

Dari hasil analisis kebutuhan yang telah dilakukan, kegiatan pembelajaran yang dilakukan oleh guru khususnya mata pelajaran matematika menggunakan buku paket dan papan tulis sebagai media untuk menuliskan materi pelajaran, kemudian guru menjelaskan materi tersebut lalu dilanjutkan dengan memberikan contoh soal, selanjutnya menurut penjelasan guru diketahui bahwa pada materi bangun datar pembelajaran yang dilakukan dengan mengggunakan media gambar dan media yang ada disekitar yang tentunya disesuaikan dengan materi yang akan dibahas. Oleh karena itu peneliti menyusun media pembelajaran pop up book, agar siswa tertarik dalam mempelajari matematika seperti yang dikemukakan Dzuanda dalam (Pramesti, 2015) pop up book adalah sebuah buku dimana pada bagian buku tersebut dapat bergerak atau memiliki unsur tiga dimensi dan memberikan visualisasi yang menarik, hal tersebut sejalan dengan fungsi media yaitu menarik dan mengarahkan perhatian siswa untuk berkonsentrasi kepada isi pelajaran yang berkaitan dengan makna visual yang ditampilkan menyertai teks materi pembelajaran (Munadi, 2010).

Selanjutnya pada analisis materi, materi yang terdapat dalam media pembelajaran telah melalui penyesuian materi yang dibutuhkan di kelas IV Sekolah Dasar, materi yang akan dibahas meliputi bangun datar (persegi, persegi panjang dan segitiga), sesuai dengan komponen untuk pembelajaran matematika disekolah dasar dalam Depdiknas yakni menentukan sifat dan unsur berbagai bangun datar dan bangun ruang sederhana, termasuk penggunaan sudut, keliling, luas, dan volume (Susanto, 2016).

Setelah dilakukan analisis terhadap tiga aspek tersebut, lalu dilakukan tahapan desain produk, pada tahapan desain produk yakni, pembuatan rancangan awal dengan menentukan backgroun dan mengumpulkan gambar-gambar yang akan digunakan dalam media, membuat desain, mencetakan gambar desain, melakukan pemotongan gambar yang telah dicetak, penyusunan buku dengan teknik-teknik pop up book. Teknik yang digunakan pada pop up book berbasis budaya Banten terdapat 3 teknik yakni, Teknik Flaps, Teknik Internal Stand dan Teknik Pull-tabs (Muvida Indah Kusuma, 2017). Setelah menentukan teknik yang digunakan kemudian melakukan penempelan gambar dengan teknik tersebut. Setelah semua tersusun tahapan selanjutnya ialah finishing, dimana pada tahapan ini hanya menggabungkan setiap halaman pop up kemudian dilakukan penjilidan menjadi sebuah buku.

Media pop up book yang telah jadi belum menjadi produk akhir yang layak untuk di uji cobakan, karena perlu melalui tahap validasi dari 2 ahli yakni 2 ahli materi dan 2 ahli media. Penilaian yang dilakukan oleh ahli materi yang melibatkan guru hanya 1 kali tahap penilaian. Pada tahap penilaian 
yang dilakukan oleh ahli materi terdapat revisi atau perbaikan. Pendapat ahli materi mengenai perbaikan produk dari segi penulisan kalimat pada contoh soal. Beberapa kalimat kurang sesuai sehingga perlu diperbaiki karena sesuai dengan salah satu fungsi dari media menurut Kemp \& Dayton (Arsyad, 2011) ialah menyajikan informasi, sehingga penyajian informasi harus jelas untuk mempermudah siswa memahaminya.

Dari penilaian kedua ahli dan masukan yang didapat untuk memperbaiki produk, maka didapatkan media pop up book dengan kategori yang sangat layak untuk diujicobakan di sekolah dasar, hasil penggabungan penilaian kedua ahli materi yakni mencapai presentase 94\% masuk pada kriteria "Sangat Layak".

Adapun hasil penilaian yang dilakukan oleh kedua ahli media berdasarkan instrumen penilaian, peneliti uraikan sebagai berikut. Untuk penilaian media pop up book dibagi dalam 2 aspek yakni aspek kelayakan isi dan aspek kelayakan penyajian. Pada aspek kelayakan isi terdapat 4 indikator penilaian yakni kesesuaian materi dengan $\mathrm{KD}$, keakuratan materi, pendukung materi pembelajaran, dan kemutakhiran materi sedangkan pada aspek kelayakan penyajian terbagi dalam 2 indikator saja yakni penyajian pembelajaran dan kelengkapan penyajian.

Sementara itu, penilaian yang dilakukan oleh ahli media dilakukan I kali tahap penilaian dengan tingkat validitas yang didapatkan dari hasil penggabungan penilian kedua ahli media yakni mencapai presentase 84\% dengan kategori "Sangat Layak". Pada penilaian yang dilakukan oleh ahli media tidak terdapat revisi namun ahli media memberikan masukan agar menambahkan cara penggunaan media dengan tujuan untuk menyempurnakan dan mempermudah siswa dalam menggunakan media pop up book berbasis budaya Banten.

Setelah tahap validasi media pembelajaran pop up book dilakukan, langkah selanjutnya yaitu melakukan uji coba terbtas. Tahap uji coba terbatas dilakukan 1 kali tahap. Uji coba terbatas dilakukan dikelas IV-B. Adapun respon siswa mencapai kategori "Sangat Baik" sesuai dengan kelebihan media pop up book yakni sebagai sumber belajar yang dapat digunakan pada usia berapa saja karena pada buku tersebut memiliki halaman yang dapat diisi dengan gambar serta informasi yang di rancang dengan konsep yang telah ditentukan. Pop up book memiliki dimensi ruang, dimana buku ini bisa berbentuk tiga dimensi sehingga buku ini lebih menarik untuk dibaca (Zahro 2016). Peneliti juga melakukan penyebaran angket kepada responden (siswa) dalam penelitian ini, adapun angket yang diberikan kepada siswa untuk mengetahui respon siswa terhadap media pembelajaran pop up book.

\section{SIMPULAN DAN SARAN}

Berdasarkan penelitian yang dilakukan didapatkan kesimpulan sebagai berikut:

1. Penelitian ini menggunakan model 3-D, terdiri dari tiga tahapan yaitu; Pertama, tahap define yang terdiri dari kegiatan analisis kurikulum, analisis kebutuhan, dan analisis materi. Kedua, tahap design yang terdiri dari mendesain media dan kemudian dilanjut dengan pembuatan media pop up book. Ketiga, tahap develop yang terdiri dari validasi ahli (ahli media dan ahli materi), revisi produk, dan uji coba terbatas.

2. Tingkat validasi media pop up book melibatkan 2 ahli, yaitu ahli media dan ahli materi, adapun 2 guru sebagai ahli materi dan 2 dosen sebagai ahli media. Tingkat validitas media dari segi materi mencapai $94 \%$ yang masuk dalam kategori sangat layak, dan tingkat validitas dari segi media mencapai $84 \%$ yang masuk dalam kategori sangat layak. Berdasarkan penilaian rata-rata validasi ahli sebesar $89 \%$ dan berdasarkan pedoman konversi data kuantitatif ke 


\section{$\pi$ (Phi)}

kualitatif maka media pop up book masuk kedalam kategori "Sangat Layak".

3. Respon siswa terhadap media pop up book yang dikembangkan pada tahap uji coba terbatas dan melibatkan 19 orang responden menghasilkan presentase $84,7 \%$ yang termasuk dalam kategori "Sangat Baik".

Berdasarkan hasil penelitian dan dan pengembangan media pembelajaran pop up book pada materi bangun datar, maka peneliti memberikan saran yaitu, dengan menggunakan media pembelajaran pop up book berbasis budaya Banten dapat menambah sumber belajar bagi siswa, kegiatan pebelajaran lebih menarik, ,mempermudah siswa dalam mempelajari materi pelajaran serta mengetahui budaya Banten dan peninggalan sejarah Banten.

Saran bagi guru yakni dapat dijadikan rekomendasi sebagai pengembangan media pembelajaran serta memberikan informasi penting dan wawasan tentang media pembelajaran pop up book yang telah dihasilkan dan juga memberikan motivasi kepada guru-guru untuk meningkatkan kreatifitas dan berinovasi dalam melaksanakan pembelajaran di kelas sehingga pembelajaran akan lebih menarik serta membuat siswa antusias dan semangat dalam belajar. Kemudian saran bagi sekolah, hendaknya dapat memfasilitasi guru untuk dapat berinovasi dan mengembangkan kreativitasnya dalam membuat media pembelajaran.

\section{DAFTAR PUSTAKA}

Ali, Muhammad. (2009). Pendidikan Untuk Pembangunan Nasional. Jakarta: Grasindo

Arsyad, A. (2011). Media Pembelajaran. Jakarta: Rajagrafindo Persada.

Aunurrahman. (2010). Belajar dan Pembelajaran. Bandung: Alfabeta

Fuadi Rahmi, dkk. (2016). Peningkatan Kemampuan Pemahaman dan Penalaran Matematis Melalui Pendekatan Kontekstual. Jurnal
Dikadtika matematika. Vol. 3, No. 1, April 2016: (48)

Kusuma, M. I. (2017). "Pengembangan Media Pembelajaran Pop Up Book Materi Kubus dan Balok Untuk Siswa SMP". Skripsi: Ilmu Pendidikan, Universitas Muhammadiyah Purwokerto, Purwokerto.

Munadi, Y. (2010). Media Pembelajaran "Sebuah Pendekatan Baru". Jakarta: Gaung Persada Press.

Pramesti, J. (2015). "Pengembangan Media Pop Up Book Tema Peristiwa Untuk Kelas III SD Negeri Pakem 1". Skripsi: Pendidikan Guru Sekolah Dasar, Ilmu pendidikan, Universitas Negeri Yogyakarta, Yogyakarta.

Santi, A. N. (2016). "Problematika Pembelajaran Matematika Kelas V SD Islam Hidayatullah Semarang Tahun Pelajaran 2015/2016". Skripsi: Ilmu Tarbiyah dan Keguruan, Universitas Islam Negeri Walisongo, Semarang.

Sugiyono. (2015). Metodologi Penelitian Kuantitatif, Kualitatif dan $R \& D$. Bandung: Alfabeta.

Sukiman. (2012). Pengembangan Media Pembelajaran. Yogyakarta: Pedagogia.

Susanto, A. (2016). Teori Belajar dan Pembelajaran di Sekolah Dasar. Jakarta: Kencana Media Grup.

Trianto, (2012). Model Pembelajaran Terpadu Konsep, Strategi dan Impelemtasi dalam KTSP. Jakarta: PT Bumi Aksara

Zahro, L. (2016). "Pengembangan Buku Ajar Berbasis Multi Media Pop Up di Kelas II MI Al-Azhar". Skripsi: Universitas Islam Negeri Maulana Malik Ibrahim Malang. 